it continually, and trying to make me understand the poetry of some speculations, which only amused me, from seeing that it was deep mathematics with which he was delighted, as with a romance."

"Murray has sold 1,750 copies of my book in the last ten months, so that I have the satisfaction of being much read. . . ."

\section{The Science of Education}

AN advertisement in The Times for July 6, 1835, ran as follows : "A Course of Seven Lectures on the Science of Education will be delivered in Willis's great Rooms, 26 King-street, St. James's, commencing tomorrow the 7th of July at 3 o'clock, and continued on Tuesdays, Thursdays and Saturdays at the same hour, by the Rev. R. J. Bryce, LL.D., Principal of the Belfast Academy. The object of these lectures is to reduce the art of teaching and managing children to scientific principles, derived from the known laws of the human mind; to point out the best methods in each department of education; and to show the means of varying those methods to correspond with the endless varieties which occur in the minds of children. The formation of such a science of education has been spoken of as a great desideratum by the most eminent philosophers of modern times, and has long been anxiously wished for by the most distinguished friends of education. . . The proceeds of the lectures, after paying necessary expenses, will be placed at the disposal of a committee of the audience, to be by them applied to the promotion of some object connected with the improvement of education."

\section{J. D. Forbes in the Pyrenees}

The travels of Prof. J. D. Forbes began when, as a boy of sixteen years of age, he visited France, Germany and Italy. This journey led to the publication of his first scientific memoir, "Remarks on Mount Vesuvius", which appeared anonymously in the Edinburgh Journal of Science. Six years later, in 1832, he first visited Switzerland, from which he hastened home to enter successfully for the chair of natural philosophy at Edinburgh. His favourite subject was heat, and in the summer of 1835 he set out to study the hot springs of the Pyrenean valleys. His letters and journal contain many interesting observations on his travels. On July 7, 1835, he went from Bordeaux to Pau by diligence and on July 9 he records : "A splendid morning. . . . The whole range of the Hautes Pyrenées was now uncovered, and presented as noble and rugged an outline as I ever saw. . . ." He then went to EauxBonnes and to Eaux-Chaudes with its splendid gorge. "If ever there was a valley of disruption," he wrote, "it is this one, though I do not pretend always to decide. This confirms Dr. Daubeny's theory of hot springs, especially as these waters issue just at the junction of the granite and limestone. The limestone rises always to the granite, more as it approaches it, and at last is elevated in horizontal strata on the top of it-at least so far as I can judge from a very imperfect examination. What confirms the view of the granite being the upheaving agent is that the valley of disruption is perpendicular in direction to the strata (Hopkins' theory). It is remarkable that there are signs of water wearing (obviously not weathering) on the rocks at a great height above the torrent."

\section{Societies and Academies}

\section{LONDON}

Royal Society, June 27. W. A. Bone, R. P. Fraser, and W. H. Wheeler : A photographic investigation of flame movement in gaseous explosions. A new view of the detonation wave in gaseous explosions is advanced. It can no longer be regarded as simply a homogeneous shock wave in which an abrupt change in pressure in the vicinity of the wave-front is maintained by the adiabatic combustion of the explosive medium through which it is propagated, but it must now be viewed as a more or less stable association, or coalescence, of two separate and separable components, namely, of an intensively radiating flame-front, with an invisible shock wave immediately ahead of it. According to the new view, detonation in an explosive gaseous medium is the propagation through it, as a wave, of a condition of intensive combustion, initiated and maintained in a shock wave by radiation from an associated flame-front; and spin ensues whenever the conditions are such that the radiation from an attenuated flame-front causes a localised intensive excitation of molecules in the shock wave just ahead of it. The experimental part of the work has been mainly concerned with detonations in a moist $2 \mathrm{CO}+\mathrm{O}_{2}$ medium, which has proved to be specially adapted to the elucidation of the dual character of the phenomenon. O. H. Latter and H. EltringHAM: The epigamic behaviour of Euploea (crastia) core asela, Moore (Lepidoptera, Danainæ) with a description of the structure of the scent organs. Observations in the field show that the male butterfly diffuses, from brushes exserted from the abdomen, a scent which attracts females from a distance. While male scent organs of great complexity are found in many insects, no evidence has previously been obtained of the distant action of such organs, termed here 'telegamic'. B. F. J. SchonLand, D. J. MALAN, and H. Collens: Progressive lightning (2). A general account, based on the study of 95 flashes photographed with the Boys and other cameras, is given of the mode of development of the lightning discharge. It is shown that the leader-return stroke sequence is present in almost all the cases examined. Leaders to first strokes are stepped, those tosubsequent strokes generally dart-like. In certain cases of very slow dart leaders, these change to the stepped form at their lower ends. Slower leader velocities and higher intensities of return strokes are associated with longer time-intervals between strokes and their predecessors; hence the degree of pre-existing ionisation in the channel governs the velocity of the dart-leader. The downward-branching of lightning and its characteristic zig-zag form arise during the stepped leader process before the first return stroke.

\section{PARIS}

Academy of Sciences, May 20 (C.R., 200, 1697-1804). Charles Achard and Augustin Boutaric: The physicochemical study of the changes undergone by the blood serum under the influence of heat. The diluted serum is treated with charcoal, and the quantity of the latter determined which completely removes the colloidal substances, use being made of the surface tension. Data are given for results obtained by heating for various times at temperatures between $55^{\circ} \mathrm{C}$. and $62^{\circ} \mathrm{C}$. Pierre Weiss : The 
equation of state of fluids. The negative internal pressure at high temperatures. Charles Nicolle and Mme. Hónese Sparrow: Infection by the conjunctiva of small apes with the murin I typhus virus from Tunisian rats. JeAN Mirguet : The continuity of the biparatingent. PAUL AlmXandrofr' : Suites of topological spaces. ADOLPHE BUHL: The integral of Stieltjes. LadisLas FeJES: Cauchy's exponential series. N. GÜNTHER : The resolvant of certain integral Hermite equations. A. KolMogoroFr : The Laplace transformation in linear spaces. JEAN BRAitzEFF : The fundamental formula of the theory of Dirichlet's series. FloRIN VAsILEsco : Remarks on the various methods of solution of the problem of Dirichlet. PAUL LÉvY : A tensorial form of the functional differential equations of Green's and Neumann's functions. Lfín BRrLLOUIN : The transversal physical waves in wave mechanics and the harmonic oscillator in four dimensions. PAUL BERNARD : The measurement of the pressures developed by explosive substances. A comparison of crusher pressures with true pressures measured by a piezoelectric dynamometer. The results with a light and heavy piston in the crusher manometer are compared graphically. DANIEL BARBIER, DANIEL ChaLONGe and ETIENNE VASSY: The interpretation of the continuous absorption of hydrogen in stars of early spectral types. AUren PoTop: The thermal conductivity of metals examined in the form of small bars. JACQUES VAN MrEGHEM : The velocity of transport of electromagnetic energy. CHARLES BECHARD : The electrolytic deposit of alloys of copper and tin. PIErRe Sür : The conductivity and hydrolysis of the sodium niobates. The orthoniobate is completely hydrolysed : the salt, $7 / 6 \mathrm{Na}_{2} \mathrm{O}, \mathrm{Nb}_{2} \mathrm{O}_{5}$, is strongly hydrolysed and in equilibrium with the metaniobate. AURELIAN NABERNIAC : The study of a characteristic band of the $\mathrm{OH}$ group in the near infra-red. MME. LUCIE LeferbvRE: The absorption spectrum of ozone in the region of the photographic infra-red. The tubes employed were equivalent to a column of $50 \mathrm{~cm}$. of pure ozone : the region explored was between 6500 A. and 10,000 A. EMrue Sevin : The play of waves, spin and numbers. Pierre Auger, Lours Leprince-RINguet and Paut Ehrenrest : The absorption of the soft fraction of the cosmic corpuscular radiation. An account of results obtained at the International Laboratory at the Jungfraujoch. Francis Perrin : The mechanism of the capture of slow neutrons by light nuclei. Mms. L. S. MathievLévy : The influence of complex formation on the adsorption of copper in ammoniacal solutions by precipitated ferric hydroxide. MLLE. M. QUINTIN : The application of Debye's theory to solutions of cadmium chloride. Charles TourneUr : Study of the action exercised by alcohol on gum arabic sols, as shown by the polarisation of the diffused light. ARAKEL TChakirian and Henri Volkringer: The Raman spectra of the bromine compounds of germanium and of tin. Comparative diagrams are given of the Raman spectra of the compounds $\mathrm{RBr}_{4}$ and $\mathrm{RHBr}_{3}$, where $\mathbf{R}$ is carbon, silicon, germanium or tin. AUgustin Maché : Contribution to the study of the determination of ozone. Comparisons of the iodide and fluorescin methods. For low concentrations of ozone the latter is more accurate. A. P. Rollet : The potassium borates. Study of the system $\mathrm{B}_{2} \mathrm{O}_{3}, \mathrm{~K}_{2} \mathrm{O}$. MAURICE BrLLY and PaUL Brasseur : The preparation of anhydrous titanium trichloride. The tetrachloride is reduced with preeipitated antimony, afterwards removing the excess of tetrachloride with carbon tetrachloride and the antimony chloride with anhydrous ether. PIERRE Carré and Henri Passedouex : The relative mobilities of the normal primary alkyl groups from $\mathrm{C}_{1}$ to $\mathrm{C}_{18}$ in their chloroformates. G. MuLLER: The oxidation of mineral oils by gaseous oxygen at moderate temperatures. The chemical nature of the oxidation of mineral oils is the same whatever their origin or previous treatment, although the amount of deposit may vary considerably. The white refined oils are most strongly oxidised. Alexandre DINCASaMuracas: The polarisation of seismic waves in the primary phase of earthquakes. LouIs FAGE : The localisation in the intermediate waters of the Pacific of the little-known Ceratolepis hamata. A single specimen of this organism was collected by the Challenger between the New Hebrides and Australia. During the last voyage of the Dana in the Pacific, Schmidt was able to collect nearly two hundred specimens of this Crustacean. The results obtained from this material are given, completing the descrip. tion given by Sars of the Challenger specimen. $\mathbf{M}$. BURGAUD : Magnetic observations in the south and south-west of China and a map of the isogonics and isodynamic lines. LouIs EMbEraER : New botanical researches in the eastern Grand Atlas. JEAN CHAze and ANDRf SARAZIN : The parasitism of mushroom beds by the mole is a reversible phenomenon. ARMAND DeHORNE : The anatomical and cytological characters of the thoracic nephridia of Sabellaria. PAUL Mathias : The evolutive cycle of a holostomid trematode, Cyathocotyle Gravieri. OCTAve DuBoscQ and MLle. Odette Tuzet : A new stage of development of the calcareous sponges. GEORGES UNGAR and MLLe. Marte Rose ZerLING: The intervention of a humoral transmission in vasodilatation known as antidromic. Arguments in favour of the existence of histaminergic nerves. MME. VÉRA DANTCHAKOFF : The equivalence of the somatic tissues in the gonads of the fowl. Pierre Grabar and ANdre Riegert : The nature of urease: approach to the study with the aid of fractional ultra-filtration. The activity of urease is intimately connected with very bulky molecules of protein nature: Sumner's crystallised urease, in aqueous solution, was the most homogeneous of the preparations studied. AUGUSTE and René Sartory, JacQues Meyer and Frédirio ARNOLD : Comparative attempts at the determination of the phosphorus and potassium contained in an arable soil by means of Hilgard's chemical method. Neubauer's biological method and that of Niklas, utilising Sterigmatocystis nigra. The Niklas method is very suitable for determining the immediate requirements of a soil. CoNSTANTIN LEvaditx and JEAN VIEUCHANGE : The inoculability of certain neurotrope viruses (herpes, poliomyelitis) through the external auditory canal.

\section{VIENNA}

Academy of Sciences, May 9. F. Wessery, K. Dinjaski, W. Iseman and G. Srnger: Bitter principles of kolombo root-kolumbin. G. KIRSCH : Viscosity and melting curves. E. HASCHEK and H. MACHE : Dependency of spark-noise on the electrode material with a rapid succession of sparks. E. CHWALla : Bulging of rhomboidal plates under pressure and shear loading. W. PAsser : Pressure distribution through an elastic layer. W. W. LEPESCHKIN : Fundamental substances of living matter (vitaids) and their significance in biology. 
The importance of 'vitaids' to life is probably due to the part they play in the structure of the consistent phase of the protoplasm. F. Roch and F. MoLL : New terenid species. F. Heritsch : Uppermost lower Devonian and lower mid-Devonian. A. Thurner : Position of the Trias in the mountains around Murau. O. GUGENBERGER : The Cardita layers of Launsdorf in mid-Carinthia and their fauna. H. REBEL: Lepidoptera from the Fgean Islands. F. WERnER et al. : Insects and arachnoids of the Agean Islands. L. FLAMM : Algebraic electrodynamics. A. Skrabal: Chemical induction. In continuation of investigations on the kinetics of intermediate reactions, those general systems are considered which can be decomposed into separate systems with different total reactions. M. Pestemer and L. WILIGUT : Ultra-violet absorption of certain aromatic hydrocarbons $(3)$; constitution of tetrahydrodiphenyl. Substances with double linkings conjugated to the benzene nucleus show a marked increase in the extinction, whereas the extinction of the benzene bands is not increased by substitution with alkylenes or olefines in which the double linking is separated from the benzene nucleus by more than one carbon atom. From this it follows that the tetrahydrodiphenyl obtained by hydrogenation of diphenyl has the constitution of the known 1phenylhexene-1. E. Abel and J. Proisu : Mechanism of the lead-chamber reaction (1); reaction between sulphurous and nitrous acids in the dilute system. A. Pongratz and G. Markgraf: Perylene and its derivatives (44). A. VERDINo and E. ScHadENDORFF : Condensations of ethyl chlorocarboxychlorate with amines and phenols. W. Kosmath : Process for measuring the momentary radon content of the open air at spas with radioactive waters. Use is made of the arrangement previously described, which consists essentially of two similar cylindrical air-tight ionisation chambers (measuring chamber and compensation chamber) of about 9 litres capacity, and a Lindemann electrometer with switch-box. T. Kormos : Revision of the small mammal remains of Hundsheim. A. WAGNER: Daily course of cosmic ultra-radiation. A reply is made to Hess's criticisms of the author's previous communication. A. Fink, P. Gross and H. Steiner : Conductivity of strong acids in mixtures of heavy and light water. Determinations have been made of the conductivities of hydrochloric and perchloric acids in about $0 \cdot 01 N$ solutions in mixtures of heavy and light water at $18^{\circ} \mathrm{C}$. The value of the equivalent conductivity of hydrochloric acid at infinite dilution falls from 377 to 250 in pure deuterium oxide, the fall being non-linear. K. UNNA and L. WALTERSKIRCHEN : Action of anti-diuretic pituitary hormone on dogs to which water is or is not given.

\section{Forthcoming Events}

[Meetings marked with an asterisk are open to the public.]

\section{Sunday, July 7}

British Museum (Natural History), at 3 and 4.30.Miss M. R. J. Edwards: "The World 50,000,000 years ago, $150,000,000$ years ago and $1,000,000,000$ years ago".*

Institute of Chemrstry, July 9-10,-Charter Jubilee Celebrations, to be held in London.

\section{Official Publications Received \\ Great Britain and Ireland}

Proceedings of the Royal Society of Edinburgh. Vol. 55, Part 1, No. 5: The Mathematical Representation of the Energy Levels of the Secondary Spectrum of Hydrogen, 2. By Dr. Ian Sandeman.
Pp. 49-61. 18. Vol. 55, Part 1, No. 6: The New Crystallography. By Prof. W. L. Bragg. Pp. 62-71. 18. (Edinburgh: Robert Grant By Prof. W. L. Bragg. Pp. 62-71. 1s. (Edinbur

The British Science Guild. Gas Defence. By J. Davidson Pratt. Pp. 18. (London : British Science Guild.) 1s.

True Temperance Scientific Committee. Monograph No. 1: The Problem of the Intoxicated Motor Driver. Pp. 15. (London: True Temperance Scientific Committee.) $2 d$.

Joint Board of Research for Mental Disease : City and University of Birmingham. Annual Report, 1934-1935. Pp. 14. (Birmingham.) Empire Cotton Growing Corporation. Report of the Fourteenth Annual General Meeting. Pp. 8. (London: Empire Cotton Growing Corporation.)

Financial and Economic Position of Basutoland: Report of the Commission appointed by the Secretary of State for Dominions Affairs. (Cmd. 4907.) Pp. viii + 225. (London: H.M. Stationery Office.) 38 . $6 d$. net.

Air Ministry: Aeronautical Research Committee : Reports and Memoranda. No. 1649 (S. 163, 195, 211, 221): Wall Interference and Depth Effect in the R.A.E. Seaplane Tank and Scale Effect Tests on Hulls of Three Sizes. By L. P. Coombes, W. G. A. Perring, D. W. Office.) 38 . net.

British Non-Ferrous Metals Research Association. Supplement to Research Monograph No. 2: Bibliography of Literature on Spectrum
Analysis. Compiled by D. M. Smith. Pp. 20. (London: British NonFerrous Metals Research Association.) 18.6d.

The Scientiflc Proceedings of the Royal Dublin Society. Vol. 21 (N.S.), No. 24: A Simple Titrametric Method for the Approximate (Dublin: Hodges, Figgis and Co.; London: Williams and Norgate, Ltd.) $6 d$.

Royal Botanic Gardens, Kew. Bulletin of Miscellaneous Information, 1934. Pp. viii $+456+66+11$ plates. (London : H.M. Stationery tion, 1934. Pp. vili 128 . 6 . net.
Offer

London Shellac Research Bureau. Technical Paper No, 2 : Identification and Analysis of Lac. By Dr. R. Bhattacharya. Pp. 28. (London: London Shellac Research Bureau.)

(London: London Shellac Research Bureau.) Experimental and Research Station, Nursery and Market Garden
Industries' Development Society, Ltd. Twentieth Annual Report, 1934. Pp. 107. (Cheshunt : Experimental and Research Station, Nursery and Market Garden Industries' Development Society, Ltd.) Board of Education. Report of the Advisory Council of the Science Museum for the Year 1934. Pp. 52. (London: H.M. Stationery
Office.) 18. net.

\section{Other Countries}

Obras completas y Correspondencia cientifica de Florentino Ameghino. Vol. 15: La perforación astragaliana y el credo. Edición Oflcial ordenada por el Gobierno de la Provincia de Buenos Aires. Dirigida por Alfredo J. Torcelli. Pp. $730+40$ plates. (La Plata.)

U.S. Department of Agriculture. Circular No. 346: Insect Parasites and Predators of Insect Pests. By Curtis P. Clausen. Pp. 22. (Washington, D.C.: Government Printing Office.) 5 cents.

Chemical Industry's Contribution to the Nation, 1635-1935: a Record of Chemical Accomplishment, with an Index of the Chemicals made in America. A Supplement to Chemical Industries, May 1935, published in celebration of the Tercentenary of the founding of the American Chemical Industry by John Winthrop, Jr. Pp. 176. (New York : Chemical Industries.) Paper, 1 dollar; cloth, 2 dollars.

Annuario della Reale Accademia d'Italia. 6: 1933-1934. Pp. $383+4$ plates. (Roma : Reale Accademia d'Italia.) 25 lire.

Imperial College of Tropical Agriculture. Fourth Annual Report on Cacao Research, 1934. Pp. $87+4$ plates. (Trinidad: Government Printer.) 58.

Report on the Administration of the Government Museum and Public Gardens, Trivandrum, for the Year 1109 M.E. Pp. 13. (Trivandrum : Government Museum.)

Comptes-rendus des Travaux du Laboratoire Carlsberg. Vol. 20, No. 11: Studies on Enzymatic Histochemistry, 9-13. By D. Glick, Heinz Holter, K. Linderstrøm-Lang and A. Søeborg Ohlsen. Pp. $127+1$

plate. (Copenhague: $\mathrm{H}$ Hagerup.) $6.75 \mathrm{kr}$.
Survey of India. Geodetic Report 1934. Pp. xii $+143+32$ plates. (Dehra Dun : Survey of India.) 3 rupees; $58.3 d$.

Svenska Linné-Săllskapets Årsskrift. Årgång 18, 1935. Pp. v+ 172. (Uppsala : Almquist and Wiksells Boktryckeri A.-B.)

Union of South Africa : Department of Mines. Geological Series, Bulletin No. 3: Gypsum in the Union of South Africa. By Dr. B. Travertine Deposits near Port St. Johns. By Dr. W. Kupferburger. Travertine Deposits near Port St. Johns. By .

Pp. 15. 6d. (Pretoria : Government Printer.) Straits Settlements. Annual Report of the Director of Gardens for
the Year 1934. By R E. Holttum. Pp. 9. (Singapore : Government Printer.) 50 cents; $18.2 d$.

Uganda Protectorate. Annual Report of the Geological Survey Department for the Year ended 31st December 1934. Pp. 12. (Entebbe : Government Printer.) 18.

Annuaire de l'Académie Royale de Belgique, 1935. Pp. 138+4 plates. (Bruxelles: Académie Royale de Belgique.)

Observatoire de Zi-ka-wei. Annales de l'Observatoire de Zô-Sè (Chine). Tome 20: Coopération de l'Observatoire de Zi-ka-wei à la Révision International des Longitudes, Octobre-Novembre 1933. Par R. P. Pierre Lejay, R. P. Maurice Burgaud, R. P. E. de la
Villemarqué. Pp. $99+5$ plates. (Sung-kiang : Observatoire de Zô-Sè.) 